\title{
Extent of misuse and dependence of codeine- containing products among medical and pharmacy students in a Nigerian University
}

\section{Wuraola Akande-Sholabi ( $\nabla$ wuradol@gmail.com )}

University of Ibadan https://orcid.org/0000-0003-0869-1726

\section{Rasaq Adisa}

Department of Clinical Pharmacy and Pharmacy Administration, Faculty of Pharmacy, University of Ibadan

\section{Olayinka S llesanmi}

Department of Community Medicine, College of Medicine, University of Ibadan, Nigeria

\section{Ayomide Esther Bello}

Department of Clinical Pharmacy and Pharmacy Administration, Faculty of Pharmacy, University of Ibadan, Nigeria

\section{Research article}

Keywords: Codeine-containing products, Opioids misuse, Dependency, Medical and Pharmacy students

Posted Date: August 12th, 2019

DOI: https://doi.org/10.21203/rs.2.12661/v1

License: (1) This work is licensed under a Creative Commons Attribution 4.0 International License.

Read Full License

Version of Record: A version of this preprint was published at BMC Public Health on December 1st, 2019. See the published version at https://doi.org/10.1186/s12889-019-8074-5. 


\section{Abstract}

Background Misuse and dependency of opioids especially codeine-containing products is of increasing global concern. Inappropriate use of opioids among healthcare students could affect quality of service and ethical conducts of these future professionals, thereby putting the society at risk. Objectives To evaluate knowledge and perception of medical and pharmacy students in a Nigerian tertiary University on use of opioids with focus on codeine-containing products. Methods A cross-sectional survey among 335medical and 185-pharmacy students from University of Ibadan, Nigeria, between September and December 2018, using a semi-structured questionnaire. Results Codeine-containing cough syrup was the most commonly used opioid-products (163;31.3\%) among the students. Majority (469;90.2\%) had good perception about codeine-containing products, while 319(61.3\%) had poor knowledge of opioids usage. Logistic-regression shows that students who experienced some side-effects they would like to experience again, 36.31[AOR=36.31, 95\% Cl: (10.89-121.12)] and those pressured into using codeine-containing products, $11.77[\mathrm{AOR}=11.77, \mathrm{Cl}=95 \%$ (2.50-55.38)] had more tendency of misuse. Conclusion Misuse of codeine-containing products among medical and pharmacy students is obvious. Peer-influence and experience of some effects are significant predictors of misuse among the students. Thus, healthcare curriculum should incorporate preventive program on medication misuse, while policy that favours peersupport program on medication misuse is advocated for healthcare students.

\section{Background}

Globally, the incidence of misuse of medicines including codeine, among higher education students ranges from $4.7 \%$ to $67 \%^{1-9}$. In Nigeria, the misuse of codeine containing products, especially cough syrup among adolescent is widespread ${ }^{10,11}$ this led to a documentary on British Broadcasting Corporation (BBC) in May 2018 titled "Sweet Sweet Codeine"; and the subsequent ban on the importation and sale of codeine as an active pharmaceutical ingredient by the National Agency for Food and Drug Administration and Control (NAFDAC) in Nigeria.

Misuse of medicines, including codeine, is defined as the use of drug with or without prescription, outside of acceptable medical practice or medical guidelines, for recreational reasons and when self-medicating at higher doses and for a longer period than recommended. Misuse is also considered problematic consumption where risks and adverse consequences outweigh the benefits ${ }^{12-14}$. There is increased concern by the global public health and medicines regulatory body with focus on the intentional or unintentional misuse of medicinal opioids, especially because of its attendant consequences on the youths and society at large 15,16 .

In addition, the lifestyle of health care professionals plays an essential role and has a significant effect on the patients, clients and the society ${ }^{17}$. Misuse of medication by the health care professionals could affect their professional conduct and endanger the quality of the health care services provided, possibly putting the public at risk ${ }^{18}$. Consequently, to protect the wellbeing of health care professionals and the 
standard of upcoming health care services delivered, it is imperative to evaluate health care students' who are the future healthcare professional on medication misuse.

Polling analytics databank strategy found that marijuana, codeine and alcohol are the top three drugs and substances mostly misused and abused in Nigeria, particularly amongst the teenagers and young adults aged between $15-29$ years ${ }^{19}$. Codeine (3-methylmorphine), a weak opiate is one of the most widely accessible and commonly used opiates worldwide, particularly because of its analgesic, antitussive and anti-diarrhoeal properties ${ }^{20}$. Although, codeine is considered a weak opiate, it still possess the potential for misuse and abuse, as well as dependence and has numerous side effects, such as sedation, euphoria and constipation among others ${ }^{14,21}$. In Nigeria and some other developing countries, studies that evaluate extent of use and misuse of opioid containing substance among youths is scarce, thus a need for this study, which aimed to assess the knowledge and perception of codeine containing products among healthcare students. Opinion on the risks associated with the use of codeine containing products among health care students was also explored, with a view to identify areas of contribution for future preventive programs among the healthcare students.

\section{Methods}

\section{Study design and setting}

A cross-sectional study conducted among 335 medical and 185 pharmacy students from the University of Ibadan, Nigeria, between September to December 2018. University of Ibadan is the premier University in Nigeria, with most of the courses as old as the University. In Nigeria, Bachelor of Pharmacy degree is a 5year programme, while Bachelor of Medicine and Surgery degree is a 6-year programme.

\section{Sample size determination}

Sample size was estimated using Raosoft sample size calculator (http:// www.raosoft.com/samplesize.html), at $95 \%$ confidence interval and $5 \%$ margin of error, while considering a $50 \%$ non-response rate. Based on that assumptions, a target size of 297 was calculated. However, considering the nature of the study among students' population with possibility of higher non-response rate. An attrition rate of close to $100 \%$ that will allow for a large sample size was decided. Thus, a target sample of approximately 590 was subsequently used to guide enrolment of participants.

\section{Inclusion and exclusion criteria}

All consenting male and female students in the first, second, third and fifth year of the Faculty of Pharmacy and College of Medicine, University of Ibadan were included. Students in the fourth-year from the Faculty of Pharmacy, and fourth-and sixth-year from the College of Medicine were excluded.

\section{Data collection procedure}


At each level in each faculty, a compulsory course for the students was identified. Students were approached shortly after the end of the course, briefed on the objectives and purpose of the study. Subsequently, voluntary verbal informed consent was sought from the students and those who gave consent for participation were administered the questionnaire. Questionnaire distribution continued every day of the week from each Faculty by the principal investigators. Participants were assured of their anonymity and confidentiality of response. Each questionnaire took about 20 to 25 minutes to complete after which the questionnaire was returned and checked for completeness. Measure were put in place to ensure that no student filled more than one questionnaire. This was achieved by coding of each questionnaire administered to the students in each faculty to avoid duplication.

\section{Date collection}

The main instrument for data collection was a pre-tested semi-structured questionnaire which comprised four sections. Section A obtained the socio-demographic information. Section B contained questions that explore the use of opioid containing products, most especially codeine. Section C explored students' feeling after usage of codeine containing products. Section D contained 9- item questions with 5 points Likert scale response option ranging from strongly agree (5) to strongly disagree (1) to explore and evaluate students' perception of the risk associated with the use of codeine containing products.

\section{Pretest/validation of questionnaire}

The questionnaire was assessed for content validity by two academic scholars with public health expertise. Pretest was done among 40 randomly selected students from another Faculty which was not part of the study. Feedback from the pretest and validity assessments led to minor modifications in the questionnaire.

\section{Statistical analysis}

Data were coded, sorted, and analysis using SPSS (version 23). Descriptive statistics including frequencies and percentages were used to summarize the data. Five knowledge questions were asked, respondents with at least four correct answers were categorized to have good knowledge score. Nine-item questions with 5 points Likert scale response with option ranging from strongly agree ( 5 points) to disagree (1 point) was used to assess perception. Maximum attainable score for the 9-item statement on perception was 45 , respondents with at least $36(80 \%)$ score were categorized to have good perception. Chi-square statistics was used to assess association between sociodemographic characteristics and binary categories of knowledge and perception on use of codeine-containing products. Predictors of misuse/abuse of codeine containing products was determined using logistic regression. The level of statistical significance was set at $p<0.05$.

\section{Ethics approval}

Ethics approval for the study was obtained from the joint University of Ibadan/University College Hospital Institution Review Board with approval number EC/18/0299. 


\section{Results}

A total of 590 questionnaires was administered to the students, only 520 were completely filled, giving a response rate of $88.1 \%$. Two hundred and sixty-three (50.6\%) were male, $333(64.0 \%)$ were aged 20 years and above, with a mean age of $20.7 \pm 2.8$ years. Most of the students $179(34.4 \%)$ were in $3^{\text {rd }}$ year, while the least $53(10.2 \%)$ were in the first year. Medicine and surgery students were $335(64.4 \%)$ and pharmacy students were 185 (35.6\%). Codeine-containing cough syrup 163 (31.3\%) was the most commonly used opioid containing products among the students, followed by Co-codamol $8(1.5 \%)$ as shown in Table 1.

Table 2 shows the assessment of knowledge of the use of opioid-containing products among the respondents. About two-third $(319,61.3 \%)$ had poor knowledge. The perception of the respondents on the use of codeine-containing products, is shown in Table 3. Majority, 469 (90.2\%) had good perception.

Relationship between the respondents' year of study and perception to the use of codeine-containing products is shown in Table 4. The first year had the least perception with lower mean rank when compared with other year of study, $(p<0.05)$.

Association between relevant demographic characteristics of respondents' knowledge and perception scores is shown in Table 5. Pharmacy students $(87,47 \%)$ had significantly better good knowledge about opioid usage when compared to their medical students' counterpart (114,34\%), $p=0.004$.

Table 6 shows the predictors of misuse/abuse of codeine-containing products among respondents. The odds of codeine abuse/misuse were 36.31[AOR=36.31, 95\% Cl: (10.89-121.12)] among those who experienced some side effects they would like to experience again. Respondents who were pressured into using codeine-containing product had about 12 times odds of misusing/abusing codeine $11.77[\mathrm{AOR}=11.77, \mathrm{Cl}=95 \%(2.50-55.38)]$.

Table 1: Socio-demographic characteristics and profile of opioids-containing products used by respondents $(n=520)$ 


\section{Variable}

Frequency

(\%)

Gender

Male

$263(50.6)$

Female

$257(49.4)$

Age (year)

16-20

$187(36.0)$

$\geq 20$

$333(64.0)$

Mean age \pm Standard deviation

20.7

Level of study

2.8years

100

$53(10.2)$

200

$137(26.3)$

300

$179(34.4)$

500

$151(29.0)$

Faculty

Medicine and surgery

Pharmacy

Profile of opioids-containing products

Diphenhydramine+dextromethorphan with codeine cough syrup 91 (17.5) (BenylinÒ)

Ammonium chloride+diphenyhydramine with codeine cough syrup 66 (12.7) (EmzolynÒ)

Paracetamol with codeine (Cocodamol Ò)

Dextromethorphan + diphenhydramine with codeine cough syrup $6(1.1)$ (MyasedylÒ)

Hydrocodone

Oxycodone

Table 2: Knowledge on opioid-containing products among respondents $(n=520)$ 


\begin{tabular}{|c|c|c|}
\hline Knowledge question & $\begin{array}{l}\text { Correct } \\
\text { answer } \\
\text { n (\%) }\end{array}$ & $\begin{array}{l}\text { Wrong } \\
\text { answer } \\
\text { n (\%) }\end{array}$ \\
\hline $\begin{array}{l}\text { 1.Category of people who can use opioid } \\
\text { (Answer: adults and children) }\end{array}$ & $242(46.6)$ & $278(53.4)$ \\
\hline $\begin{array}{l}\text { 2.Category of people who cannot use opioid. } \\
\text { (Answer: None of adults and children) }\end{array}$ & $12(2.3)$ & $508(96.7)$ \\
\hline $\begin{array}{l}\text { 3.Can opioid use lead to dependence/addiction } \\
\text { (Answer: Yes) }\end{array}$ & $472(90.8)$ & $48(9.2)$ \\
\hline $\begin{array}{l}\text { 4.Addiction is defined as a chronic relaxing brain disease that is } \\
\text { characterized by compulsive drug seeking and use despite } \\
\text { harmful consequences. } \\
\text { (Answer: Yes) } \\
\text { 5.Drug dependence is a medical term that refers to the state of } \\
\text { craving a certain drug in order to function normally. }\end{array}$ & $479(92.1)$ & $41(7.9)$ \\
\hline \multicolumn{3}{|l|}{ (Answer: Yes) } \\
\hline Distribution of scores & $\begin{array}{l}\text { Frequency } \\
\text { (\%) }\end{array}$ & \\
\hline 0 & $3(0.6)$ & \\
\hline 1 & $7(1.3)$ & \\
\hline 2 & $35(6.7)$ & \\
\hline 3 & $274(52.7)$ & \\
\hline 4 & $199(38.3)$ & \\
\hline 5 & $2(0.4)$ & \\
\hline Cut off score & $\begin{array}{l}\text { Frequency } \\
\text { (\%) }\end{array}$ & Remark \\
\hline$<4$ & $319(61.3)$ & $\begin{array}{l}\text { Poor } \\
\text { knowledge }\end{array}$ \\
\hline$\square 4$ & $201(38.7)$ & $\begin{array}{l}\text { Good } \\
\text { knowledge }\end{array}$ \\
\hline
\end{tabular}

$*$ Maximum obtainable score $=5$

Table 3: Respondents' perception on the use of codeine-containing products $(n=520)$ 


\begin{tabular}{|c|c|c|c|c|c|c|}
\hline Variable & $\begin{array}{l}\text { S A } \\
\text { n (\%) } \\
\end{array}$ & n (\%) & U & n (\%) & $\begin{array}{l}\text { S D } \\
\text { n (\%) } \\
\end{array}$ & $\begin{array}{l}50^{\text {th }} \\
\text { percentile }\end{array}$ \\
\hline $\begin{array}{l}\text { 1.Codeine/codeine containing } \\
\text { products can be abused }\end{array}$ & $\begin{array}{l}399 \\
(76.7)\end{array}$ & $103(19.8)$ & $9(1.7)$ & $3(0.6)$ & $6(1.2)$ & 5 \\
\hline $\begin{array}{l}\text { 2.Codeine abuse/misuse can } \\
\text { lead to dependency }\end{array}$ & $\begin{array}{l}397 \\
(76.3)\end{array}$ & $115(22.1)$ & $7(1.6)$ & 0 & $1(0.2)$ & 5 \\
\hline $\begin{array}{l}\text { 3.Codeine abuse/misuse can } \\
\text { affect psychological well-being }\end{array}$ & $\begin{array}{l}355 \\
(68.3)\end{array}$ & $141(27.1)$ & $19(3.7)$ & $4(0.8)$ & $1(0.2)$ & 5 \\
\hline $\begin{array}{l}\text { 4.Codeine abuse/misuse can } \\
\text { lead to neurological side } \\
\text { effects }\end{array}$ & $\begin{array}{l}332 \\
(63.8)\end{array}$ & $146(28.1)$ & $37(7.1)$ & $4(0.8)$ & $1(0.2)$ & 5 \\
\hline $\begin{array}{l}\text { 5.Codeine abuse/misuse can } \\
\text { lead to socially unacceptable } \\
\text { behavior }\end{array}$ & $\begin{array}{l}336 \\
(64.6)\end{array}$ & $147(28.3)$ & $26(5.0)$ & $11(2.1)$ & 0 & 5 \\
\hline $\begin{array}{l}\text { 6.Codeine abuse/misuse can } \\
\text { affect pattern of spending }\end{array}$ & $\begin{array}{l}278 \\
(53.5)\end{array}$ & $161(31.0)$ & $\begin{array}{l}66 \\
(12.7)\end{array}$ & $13(2.5)$ & $2(0.4)$ & 5 \\
\hline $\begin{array}{l}\text { 7.Codeine abuse/misuse can } \\
\text { result in accidental overdose }\end{array}$ & $\begin{array}{l}295 \\
(56.7)\end{array}$ & $185(35.6)$ & $34(6.5)$ & $5(1.0)$ & $1(0.2)$ & 5 \\
\hline $\begin{array}{l}\text { 8.Codeine abuse/misuse can } \\
\text { result in life- threatening } \\
\text { withdrawal symptoms }\end{array}$ & $\begin{array}{l}295 \\
(56.7)\end{array}$ & $185(35.6)$ & $34(6.5)$ & $5(1.0)$ & $1(0.2)$ & 5 \\
\hline $\begin{array}{l}\text { 9.Codeine abuse/misuse can } \\
\text { cause reduced fertility in males } \\
\text { and females }\end{array}$ & $\begin{array}{l}129 \\
(24.8)\end{array}$ & $76(14.6)$ & $\begin{array}{l}299 \\
(57.5)\end{array}$ & $16(3.1)$ & - & 3 \\
\hline Distribution of scores (\%) & Freque & ncy (\%) & & & & \\
\hline$<60$ & & $2(0.4)$ & & & & \\
\hline 60-79 & & $49(9.4)$ & & & & \\
\hline $80-100$ & & 469 (90.2) & & & \multirow{2}{*}{\multicolumn{2}{|c|}{ Remark }} \\
\hline Cut-off & & & & & & \\
\hline$<80 \%$ & & $51(9.8)$ & & & Poor per & rception \\
\hline ( 80\% & & $469(90.2)$ & & & Good pe & rception \\
\hline
\end{tabular}

Maximum obtainable score $=45$; \%individual score $=$ score obtained by an individual , by total obtainable score $\mathrm{x} 100$. Strongly agree $(\mathrm{SA})=5$, agree $(\mathrm{A})=4$, undecided $(\mathrm{U})=3$, disagree $(\mathrm{D})=2$, strongly disagree $(\mathrm{SD})=1$

Table 4: Association between students' year of study and perceptions on use of codeinecontaining products $(n=520)$ 


\begin{tabular}{|c|c|c|c|c|}
\hline ent & Level & $\overline{\mathrm{N}}$ & $\begin{array}{l}\text { Mean } \\
\text { Rank }\end{array}$ & $\begin{array}{l}\mathrm{k}-\mathrm{w}, \mathrm{p}- \\
\text { value }\end{array}$ \\
\hline \multirow[t]{4}{*}{ ne/codeine containing products can be abused } & 100 & 53 & $231.02 *$ & 0.005 \\
\hline & 200 & 137 & 240.28 & \\
\hline & 300 & 179 & $274.41 * *$ & \\
\hline & 500 & 151 & 272.70 & \\
\hline \multirow[t]{4}{*}{ ine abuse/misuse can lead to dependency } & 100 & 53 & 206.08* & $<0.001$ \\
\hline & 200 & 137 & 246.90 & \\
\hline & 300 & 179 & 274.12 & \\
\hline & 500 & 151 & $275.79 * *$ & \\
\hline \multirow[t]{4}{*}{ ine abuse/misuse can affect psychological well- } & 100 & 53 & 262.78 & 0.624 \\
\hline & 200 & 137 & 255.58* & \\
\hline & 300 & 179 & 260.80 & \\
\hline & 500 & 151 & $263.80 * *$ & \\
\hline \multirow[t]{4}{*}{ ine abuse/misuse can lead to neurological side } & 100 & 53 & $210.64^{*}$ & 0.001 \\
\hline & 200 & 137 & 241.30 & \\
\hline & 300 & 179 & $277.49 * *$ & \\
\hline & 500 & 151 & 275.28 & \\
\hline \multirow{4}{*}{$\begin{array}{l}\text { ne abuse/misuse can lead to socially } \\
\text { ptable behavior }\end{array}$} & 100 & 53 & $201.79 *$ & $<0.001$ \\
\hline & 200 & 137 & 233.83 & \\
\hline & 300 & 179 & 278.55 & \\
\hline & 500 & 151 & $283.90 * *$ & \\
\hline \multirow[t]{4}{*}{ ine abuse/misuse can affect pattern of spending } & 100 & 53 & $206.20 *$ & 0.001 \\
\hline & 200 & 137 & 255.90 & \\
\hline & 300 & 179 & 255.58 & \\
\hline & 500 & 151 & $289.57 * *$ & \\
\hline \multirow{4}{*}{$\begin{array}{l}\text { ine abuse/misuse can result in accidental } \\
\text { se }\end{array}$} & 100 & 53 & $186.46^{*}$ & $<0.001$ \\
\hline & 200 & 137 & 240.66 & \\
\hline & 300 & 179 & $281.58^{* *}$ & \\
\hline & 500 & 151 & 279.50 & \\
\hline \multirow{4}{*}{$\begin{array}{l}\text { ine abuse/misuse can result in life- threatening } \\
\text { iwal symptoms }\end{array}$} & 100 & 53 & $206.38 *$ & $<0.001$ \\
\hline & 200 & 137 & 235.99 & \\
\hline & 300 & 179 & 275.75 & \\
\hline & 500 & 151 & $283.65 * *$ & \\
\hline \multirow{4}{*}{$\begin{array}{l}\text { ine abuse/misuse can cause reduced fertility in } \\
\text { ind females }\end{array}$} & 100 & 53 & 240.95 & 0.016 \\
\hline & 200 & 137 & $286.07 * *$ & \\
\hline & 300 & 179 & 264.94 & \\
\hline & 500 & 151 & 238.90* & \\
\hline
\end{tabular}

$\mathrm{k}-\mathrm{w}$ : Kruskal-Wallis test

*Lowest mean rank indicates those who least agreed to the corresponding statement **Highest mean rank indicates those who mostly agreed to the corresponding statement Level of statistical significance $\mathrm{p}<0.05$ 
Table 5: Association between relevant sociodemographic characteristics and knowledge and perception on use of codeine-containing products $(n=520)$

\begin{tabular}{|c|c|c|c|c|}
\hline ariable & $\begin{array}{l}\text { Good perception } \\
\text { (Score } \mathrm{B} 8 \% \text { ) } \\
\text { n (\%) }\end{array}$ & $\begin{array}{l}\text { Poor } \\
\text { perception } \\
\text { (Score < 80\%) } \\
\mathrm{n}(\%)\end{array}$ & $\begin{array}{l}\text { Good } \\
\text { knowledge } \\
\text { (Score } 080 \%) \\
n(\%)\end{array}$ & $\begin{array}{l}\text { Poor } \\
\text { knowledge } \\
\text { (Score < 80\%) } \\
\text { n (\%) }\end{array}$ \\
\hline \multicolumn{5}{|l|}{ ge (years) } \\
\hline $6-20$ & 167 (89.3) & 20 (10.7) & $88(47.1)$ & 99 (52.9) \\
\hline \multirow[t]{2}{*}{20} & 302 (90.7) & $31(9.3)$ & $113(33.9)$ & $220(66.1)$ \\
\hline & {$\left[\mathrm{x}^{2}=0.260\right.$} & $\mathrm{p}$ value $=0.610]$ & {$\left[x^{2}=8.699\right.$} & $\mathrm{p}$ value $\left.=0.003^{*}\right]$ \\
\hline Iale & $235(89.4)$ & $28(10.6)$ & $93(35.4)$ & $170(64.6)$ \\
\hline \multirow[t]{2}{*}{ emale } & 234 (91.1) & $23(8.9)$ & $108(42.0)$ & $149(58.0)$ \\
\hline & {$\left[\mathrm{x}^{2}=0.423\right.$} & value $=0.515]$ & {$\left[\mathrm{x}^{2}=2.433\right.$} & $\mathrm{p}$ value $=0.119]$ \\
\hline \multirow{3}{*}{$\begin{array}{l}\text { acully } \\
\text { harmacy } \\
\text { ledicine and } \\
\text { argery }\end{array}$} & $171(92.4)$ & $14(7.6)$ & $87(47.0)$ & $98(53.0)$ \\
\hline & $298(89.0)$ & $37(11.0)$ & $114(34.0)$ & $221(66.0)$ \\
\hline & {$\left[x^{2}=1.629\right.$} & $p$ value $=0.202]$ & {$\left[x^{2}=8.490\right.$} & $\mathrm{p}$ value $\left.=0.004^{*}\right]$ \\
\hline
\end{tabular}

*Significance difference with Chi-square $\left(\mathrm{x}^{2}\right)$ test, level of significance $\mathrm{P}<0.05$

Table 6: Predictors of misuse/abuse of codeine-containing products among respondents $(n=520)$ 


\begin{tabular}{|c|c|c|c|c|c|c|}
\hline \multirow[t]{3}{*}{$\overline{l e}$} & \multirow{2}{*}{\multicolumn{2}{|c|}{$\begin{array}{l}\text { Misused/abused } \\
\text { codeine/codeine- } \\
\text { containing } \\
\text { products } \\
\text { n (\%) }\end{array}$}} & \multicolumn{2}{|c|}{$\begin{array}{l}\text { Unadjusted Odds } \\
\text { ratio }\end{array}$} & \multicolumn{2}{|c|}{$\begin{array}{l}\text { Adjusted Odds } \\
\text { ratio }\end{array}$} \\
\hline & & & \multirow[t]{2}{*}{$\begin{array}{l}\text { OR } \\
(95 \% \mathrm{CI})\end{array}$} & \multirow[t]{2}{*}{$p$-value } & \multirow[t]{2}{*}{$\begin{array}{l}\text { AOR } \\
(95 \% \mathrm{CI})\end{array}$} & \multirow[t]{2}{*}{ p-value } \\
\hline & Yes & No & & & & \\
\hline \multicolumn{7}{|l|}{$\begin{array}{l}\text { enced some side } \\
\text { I will like to } \\
\text { ence again }\end{array}$} \\
\hline & $\begin{array}{l}12 \\
(36.4)\end{array}$ & $21(63.6)$ & \multirow{2}{*}{$\begin{array}{l}39.02 \\
(13.94- \\
109.24) \\
1\end{array}$} & \multirow[t]{2}{*}{$<0.001$} & \multirow{2}{*}{$\begin{array}{l}36.31 \\
(10.89- \\
121.12) \\
1\end{array}$} & \multirow[t]{2}{*}{$<0.001 *$} \\
\hline & $7(1.4)$ & $\begin{array}{l}478 \\
(98.6)\end{array}$ & & & & \\
\hline \multirow{2}{*}{\multicolumn{7}{|c|}{$\begin{array}{l}\text { red into using } \\
\text { e-containing product }\end{array}$}} \\
\hline & & & & & & \\
\hline & $\begin{array}{l}5 \\
(25.0)\end{array}$ & $15(75.0)$ & \multirow{2}{*}{$\begin{array}{l}11.57 \\
(3.69- \\
36.29) \\
1\end{array}$} & \multirow[t]{2}{*}{$<0.001$} & \multirow{2}{*}{$\begin{array}{l}11.77 \\
(2.50- \\
55.38) \\
1\end{array}$} & \multirow[t]{2}{*}{$0.002 *$} \\
\hline & $\begin{array}{l}14 \\
(2.8)\end{array}$ & $\begin{array}{l}486 \\
(97.2)\end{array}$ & & & & \\
\hline \multicolumn{7}{|l|}{$\begin{array}{l}\text { o use regular dose of } \\
\text { sroducts to function } \\
\text { iily }\end{array}$} \\
\hline & $\begin{array}{l}3 \\
(50.0)\end{array}$ & $3(50.0)$ & \multirow{2}{*}{$\begin{array}{l}31.13 \\
(5.82- \\
166.63) \\
1\end{array}$} & \multirow[t]{2}{*}{$<0.001$} & \multirow{2}{*}{$\begin{array}{l}6.78 \\
(0.48- \\
95.46) \\
1\end{array}$} & \multirow[t]{2}{*}{0.156} \\
\hline & $\begin{array}{l}16 \\
(3.7)\end{array}$ & $\begin{array}{l}498 \\
(96.3)\end{array}$ & & & & \\
\hline \multirow{2}{*}{$\begin{array}{l}\text { ed to the use of these } \\
\text { its }\end{array}$} & $\begin{array}{l}4 \\
(66.7)\end{array}$ & $2(33.3)$ & \multirow{2}{*}{$\begin{array}{l}66.40 \\
(11.27- \\
391.15) \\
1\end{array}$} & \multirow[t]{2}{*}{$<0.001$} & \multirow{2}{*}{$\begin{array}{l}3.15 \\
(0.36- \\
27.35) \\
1\end{array}$} & \multirow[t]{2}{*}{0.299} \\
\hline & $\begin{array}{l}15 \\
(2.1)\end{array}$ & $\begin{array}{l}498 \\
(97.1)\end{array}$ & & & & \\
\hline
\end{tabular}

$* \mathrm{P}<0.05$ is a significant difference

\section{Discussion}

Pharmacy studies exploring the misuse of pharmaceutical opioids have concentrated on stronger opioids than weaker opioids like codeine which are regularly available over the counter as combination pharmaceuticals products. This study is one of the first in Nigeria conducted among medical and pharmacy students exclusively on codeine use and misuse.

Codeine-containing cough syrup (31.3\%) appears to be the most consumed opioid product by the students in their life time. Evidence of misuse of these products have been reported in many countries ${ }^{22-}$ ${ }^{25}$. The availability of these products over the counter (OTC) without the need of a prescription might 
explain easy to accessibility with little or no refusal. The intervention of a pharmacist in every sale of OTC codeine-containing product could raise awareness around codeine dependence. The regulation of access to over the counter codeine-containing products will assist to identify the patients using these products for medicinal purpose or misusing it. It has been reported that the possibility to buy codeine containing products from multiple sources, such as; the pharmacy, internet and patent medicine vendors added significantly to the potential for misuse ${ }^{26}$. These discoveries were coherent with other research into over the counter medication misuse, with the collective argument being the easy procurement and accessibility ${ }^{13,24,25}$.

Majority, over $90 \%$ of the students had good perceptions about the use of codeine-containing product, with the exception of first year students. This is not surprising as these students are the future health care professionals who will be handling these products and are expected to be exposed to this information in their curriculum and during workshops and seminars. However, $61.3 \%$ of these students have poor knowledge on the use of opioid-containing products, of these students, the pharmacy students seem to exhibit more knowledge about the products. This is expected as medication is the core focus of pharmacist and in the future, they are the custodian of medicine.

Few students reported minor dysfunction and addiction because of the use of these medication, however these were not significant after adjusting the variables. Slightly over a third of the students who have experienced a side effect of the use of codeine-containing product have misused these products and are 36 times likely to still misuse this products, similarly about a quarter of the students who were pressured into using codeine-containing products have misused these products and are 12 times likely to still misuse these products. This might insinuate possible weakness of the future health care professionals and the quality of health care services they will be providing. Consequently, an appropriate action should be taken to tackle this issue. We found that being pressured by peers was a predictor to misuse in this study, this is similar to findings in Ethiopia and Nepal where peer influence was a significant predictor for misuse among medical and other healthcare students ${ }^{3,27}$. These results suggest support courses either in the curriculum or as a workshop/seminar could be introduced to decrease inappropriate use of medications including codeine and promote awareness of possible dependence to these medications. Thus, this is likely to improve the services these future health care providers will offer in the context of counselling patients on the awareness of addiction and dependence.

\section{Limitations}

This study was conducted among medical and pharmacy students in one university, perhaps if conducted in more universities we might have a more comprehensive scenario of the misuse of codeinecontaining products among health care students. In addition, we did not include in our study, the fourth year students of pharmacy and $4^{\text {th }}$ and $6^{\text {th }}$ year medical students, as well as nursing and public health students. Thus, this may not allow for the generalization of the findings to all health care students in Nigeria. Despite this, the study had a high response rate of $88.1 \%$ and still offers a key insight into the misuse of codeine-containing products among medical and pharmacy students. 


\section{Conclusion}

The misuse of codeine-containing products among medical and pharmacy students is obvious. Peer influence and experience of some effects are significant predictors of the misuse among Nigerian medical and pharmacy students. Thus, health care curriculum should incorporate preventive program on medication misuse, while policy that favours peer support program on medication misuse is advocated for health care students.

\section{Abbreviations}

BBC - British Broadcasting Corporation

NAFDAC -National Agency for Food and Drug Administration and Control

OTC - Over the Counter

\section{Declarations}

Ethics approval and consent to participate: Ethics approval was received from the joint University of Ibadan/University College Hospital Institutional Ethical Review Board with IRB No UI/EC/18/0299.

Consent for publication: Not applicable

Availability of data and material: The datasets used and/or analysed during the current study are available from the corresponding author on reasonable request.

Competing interests: The authors declare that they have no competing interests" in this section.

Funding: This research received no specific grant from any funding agency in the public, commercial or not-for-profit sector

\section{Authors' contributions}

WAS had the original idea, developed study protocol, drafted manuscript, contributed in the data collection and data analysis. AEB developed study protocol, contributed in the data collection and data analysis. RA contributed in the data analysis. OSI contributed in the data analysis. All authors contributed to the preparation of the manuscript, read and approved the final version.

\section{References}

1. Kenna G, Wood MD. Substance use by pharmacy and nursing practitioners and students in a northeastern state. Am J Health Syst Pharm. 2004;61:921-930. 
2. Ahmadi J, Fallahzadeh H, Salimi A, Rahimian M, Salehi V, Khaghani M et al. Analysis of opium use by students of medical science. J Clin Nurs. 2006;15:379-386.

3. Deressa W, Azazh A. Substance use and its predictors among undergraduate medical students of Addis Ababa University in Ethiopia. BMC Public Health 2011;11:660.

4. Peters Jr. R, Yacoubian Jr. GS, Rhodes W, Forsythe KJ, Bowers KS, Eulian VM, et al. Beliefs and social norms about codeine and promethazine hydrochloride cough syrup (CPHCS) use and addiction among multi-ethnic college students Journal of Psychoactive Drugs. 2007;39(3):277-282.

5. Steinman K. High school students' misuse of over-the-counter drugs: A population-based study in an urban county. Journal of Adolescent Health. 2006;38(4):445-447.

6. Fischer B, lalomiteanu A, Boak A, Adlaf E, Rehm J, Mann R E. Prevalence and key covariates of nonmedical prescription opioid use among the general secondary student and adult populations in Ontario, Canada. Drug Alcohol Rev. 2013;32:276-287.

7. Acocella $\mathrm{CM}$. Using diaries to assess non prescription drug use among university students. Journal of Drug Education. 2005;35:267-274.

8. United Nations Office on drugs and crime Vienna. Drug use in Nigeria. 2018. Accessed 21 Feb 2019

9. Ihezue UH. Drug abuse among medical students at a Nigerian University; Part 1 Prevalence and pattern use. Journal of the National Medical Association 1988;8(1).

10. British Broadcasting commission BBC. Sweet sweet codeine 'Inside Nigeria's deadly cough syrup trade'. https://wwwbbccom/news/world-africa-43982302. 2018. Accessed 21 Jan 2019

11. Washingtonpost. Nigeria bans codeine cough syrup to stop an addiction epidemic. But something worse could take its place. https://wwwwashingtonpostcom. 2018. Accessed 21 Feb 2019

12. Casati A, Sedefov R, Pfeiffer-Gerschell T. Misuse of medicines in the European Union: a systematic review of the literature. Eur Addict Res. 2012;18(5):228-245.

13. Cooper R. 'Respectable Addiction' - A Qualitative Study of Over the Counter Medicine Abuse in the UK. London. Pharmacy Practice Trust. 2011.

14. Van Hout M C. Doctor shopping and pharmacy hopping: practice innovations relating to codeine. Drug Alcohol Today. 2014;14(4):219-234.

15. Van Hout M, Norman I. Misuse of non-prescription codeine containing products: Recommendations for detection and reduction of risk in community pharmacies. Int J Drug Policy. 2016;27:17-22.

16. Van Hout MC, Horan A, Santlal K, Rich E, Bergin M. 'Codeine is my companion': misuse and dependence on codeine containing medicines in Ireland. Irish Journal of Psychological Medicine. 2018;35:275-288.

17. Frank E, Segura C, Shen H, Oberg E. Predictors of Canadian physicians' counselling practices Can J Public Health. 2010;101:390-395.

18. Akvardar Y, Demiral Y, Ergor G, Ergor A, Bilici M, Ozer O.A. Substance use among medical students and physicians in a medical school in Turkey. Soc Psychiatry Psychiatr Epidemiol. 2004;39:502-506. 
19. NOI POlls Polling analytics databank strategy. Drug and substance abuse poll; Marijuana and codeine; Mostly Abused Substances in Nigeria. 2018. Accessed 21 Mar 2019

20. Derry S, Karlin SM, Moore RA. Single dose oral ibuprofen plus codeine for acute postoperative pain in adults. The Cochrane Database of Systematic Review. Cochrane Database of Sys Rev. 2015.

21. Nielsen S, Van Hout MC. Over-the-counter codeine from therapeutic use to dependence, and the grey areas in between Curr Top Behav Neurosci. 2016;34:59-75.

22. Mattoo S K, Basu D, Sharma A, Balaji M, Malhotra A. Abuse of codeine-containing cough syrups: A report from India Addiction. 1997;92(2):1783-1787.

23. Albsoul-Younes A, Wazaify M, Yousef AM, Tahaineh L. Abuse and misuse of prescription and nonprescription drugs sold in community pharmacies in Jordan. Substance Use and Misuse. 2010;45(9):1319-1329.

24. Nielsen S, Cameron J, Pahoki S. Opportunities and challenges: over-the-counter codeine supply from the codeine consumer's perspective. International Journal of Pharmacy Practice 2013;21:161-168.

25. Cooper R. J. Over-the-counter medicine abuse - a review of the literature. Journal of Substance Use 2013;18(2):82-107.

26. Foley M, Carney T, Rich E, Parry C, Van Hout M, Deluca P. Medical professionals' perspectives on prescribed and over-the-counter medicines containing codeine: a cross-sectional study. BMJ Open $2016 ; 6$.

27. Panthee B, Panthee S, Gyawali S, Kawakami N. Prevalence and correlates of substance use among health care students in Nepal: a cross sectional study. BMC Public Health. 2017;17:950. 